\title{
Synthesis of (S)-Rivastigmine
}<smiles>CC(=O)c1cccc(O)c1</smiles>

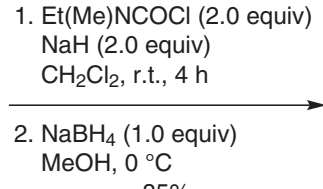

A
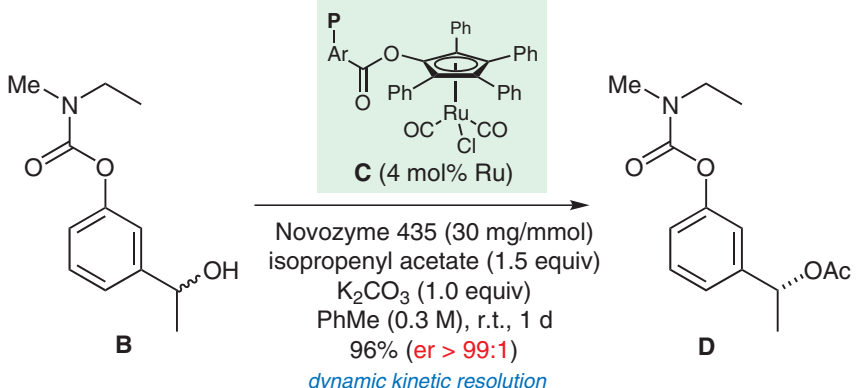

$\mathrm{K}_{2} \mathrm{CO}_{3}$ (1.0 equiv) $\mathrm{MeOH}-\mathrm{H}_{2} \mathrm{O}$, r.t., 2 h $92 \%$<smiles>CCN(C)C(=O)Oc1cccc(C(C)N(C)C)c1</smiles>

(S)-Rivastigmine
1. $\mathrm{MsCl}$ (1.3 equiv) $\mathrm{Et}_{3} \mathrm{~N}$ (3.0 equiv) $\mathrm{CH}_{2} \mathrm{Cl}_{2}, 0^{\circ} \mathrm{C}, 30 \mathrm{~min}$

2. $\mathrm{Me}_{2} \mathrm{NH}$ (4.0 equiv) THF, r.t., $2 \mathrm{~d}$ $77 \%$

\section{Key words}

\section{rivastigmine}

dynamic kinetic resolution

lipases

racemization SYNFACTInth
Significance: Rivastigmine $\left(\right.$ Exelon $\left.{ }^{\circledR}\right)$ is an acetylcholinesterase inhibitor that is prescribed for the treatment of mild to moderate dementia in patients with Alzheimer's disease and Parkinson's disease. The key step in the synthesis depicted is a dynamic kinetic resolution of the benzylic secondary alcohol B involving a lipase (Novozyme 435) coupled with a polymer-bound racemization catalyst (C).
Comment: The polymer-bound racemization catalyst $\mathbf{C}$ was prepared by heating a polymer-bound benzoyl chloride with $\left[\mathrm{Ph}_{4}\left(\eta^{4}-\mathrm{C}_{4} \mathrm{CO}\right] \mathrm{Ru}(\mathrm{CO})_{3}\right.$ in toluene for one day. The catalyst can be recycled several times. The enzymatic resolution was performed on a $1 \mathrm{mmol}$ scale. For an alternative chemoenzymatic synthesis of rivastigmine, see: J. Mangas-Sánchez et al. J. Org. Chem. 2009, 74, 5304. 